\title{
Educational Leadership in The United States and Vietnam: A Cross-Culture Comparative Study
}

\section{Bich Thi Ngoc Tran}

\section{Article history}

Received: 20 June 2021

Accepted: 02 August 2021

Published: 26 August 2021

\section{Keywords}

Comparative study, educational leadership, Vietnam, the U.S., professional development, education and training
Department of Education Reform, University of Arkansas, Fayetteville, USA Email:btt009@uark.edu

\section{INTRODUCTION}

Educational leadership is well documented in the West. Publications in the U.S., the United Kingdom, Canada, and Australia from 1960 to 2018 accounted for $83 \%$ of total Scopus-indexed journal articles (Hallinger \& Kovačević, 2019). These four countries, however, only accounted for a small fraction of the world population. There are obvious missing spots on the world map of knowledge about educational leadership, offering rich avenues for researchers.

Transnational comparative studies on educational leadership are not new, especially since the end of the $20^{\text {th }}$ century and the beginning of the $21^{\text {st }}$ century when the term "globalisation" became commonplace. Since then, comparative studies have gained even more popularity. Most scholars agree that education is among the most important independent variables in the functioning of a competitive economy. Producing "knowledge workers" is, therefore, one of the main challenges that many countries face (Walker \& Dimmock, 2002).

Particularly, studies into non-Western societies will benefit academic communities as well as policymakers and practitioners with different perspectives on school leadership (Vogel, 2015; Chen et al., 2016; Tang et al., 2011; Chao $\&$ Tian, 2011). Given the rise of new non-Western players in the global economy, comparative studies will provide potential answers as to why some countries may do better than others in education. This paper is a comparative study on school leadership, specifically the principalship, in the U.S. and in Vietnam. Utilising previous research on educational leadership and culture in the U.S. and Vietnam and survey results from the Teaching and Learning International Survey (TALIS) from the Organization for Economic Cooperation and Development (OECD) in 2018, 
I used $t$-test analyses to test several hypotheses about the differences between principals in the two countries. The findings suggest differences in age, gender, managerial experience, teaching obligation, and obtained levels of education and training between American principals and Vietnamese principals. American principals are younger, more likely to be female, and have higher levels of education compared to Vietnamese principals. Vietnamese principals are, on the other hand, older but have more managerial experience compared to American principals. Lessons from this study can be helpful for both the U.S. and Vietnam, as well as countries that share similarities in culture, society, political structure, and economy. Researchers, policymakers, and educational practitioners can broaden their knowledge on an educational leadership area that has been dominated by the West since the $20^{\text {th }}$ century.

\section{LITERATURE REVIEW}

In comparative political research, researchers use two approaches known as the 'Most Similar Systems Design' (MSSD) and the 'Most Different Systems Design' (MDSD). The decision to use either of these two approaches, argued by Anckar (2008), relies on three crucial dimensions: (1) level of variable study, in particular, systematic or sub-systematic level; (2) deductive or inductive research strategy; and (3) whether or not the dependent variable is constant or varying.

Similarly, researchers in comparative educational leadership also use MDSD and MSSD in their studies. First, researchers study educational leadership in countries with similar cultures and politics. For example, Weinstein et al. (2018) compare principal preparation in primary schools in seven Latin American countries. In this study, they examine the association between school leaders' obtained formal education and training and teachers' reports of school leadership practices. They found that the association is marginal. They theorized that the weaknesses in principal initial selection processes offer reasons for the weak association. Riley and Louis (2000) focused on the concept and practice of school leadership in Australia, Denmark, Canada, England, Scotland, the U.S., and Wales. Their edited book attempts to being fresh insights into school changes to "expand our appreciation of the many additional resources of leadership provided to schools and offered within schools" from an international perspective (p. Xv-xvi). Similarly, Brundrett (2001) and Storey (2018) compare the development of school leadership as well as preparation programs in England and the U.S. Brundrett (2011) particularly studied the historical development and school leadership training in the U.S. and England. He examined the parallels and attempts to provide lessons for both nations. Similarly, Storey compared policy shifts relating to school type diversification and corporatization and the implications for educational leader preparation programs. The study found that in the past four decades, both U.S and England experience bipartisan support for school-type diversification with raising educational standards.

Other studies use MSSD and focus on countries with relatively different cultures and politics. Su et al. (2000) conducted a comparison of profiles and preparation for urban school principals in China where they found that Chinese principals were far behind their American peers in terms of education, training, and advanced degrees. Chinese principals were mostly male and more homogeneous while American principals were more likely to be female and less homogeneous. Aravena (2017) uses lessons from Australia, England, and the U.S. to reflect on school principal preparation in Chile. Aravena finds that autonomy matters significantly in productive school administrator development. Particularly, the power to make decisions, such as selecting teaching staff and managing finances is crucial to productive principals. The study suggested that legal and bureaucratic structures in Chile are barriers to giving principals the autonomy and power that they need. Retna (2015) studies different approaches to the professional development of principals in New Zealand and Singapore. The findings suggest that principal development programs in Singapore were initiated through a centralized system that regularly and continuously appraises/monitors for leadership potential. In contrast, the same process was self-initiated in New Zealand. International educational visits were also vital in training in Singapore while it was the opposite for New Zealand.

Comparative analysis of educational leadership and management still has so much to offer, with many more countries meriting study. With rapid changes in technology and information, new initiatives in education happen regularly. It would be a tremendous loss for any country to close its borders and ignore the lessons that comparative analyses can offer. This study takes a comparative approach to examine school leadership in the U.S. and Vietnam, aiming at providing lessons for both countries in terms of education and training for school leaders.

Educational Leadership in the U.S

Educational leadership is well documented in the U.S. Hallinger and Kovačević (2019) discover that from 1960 to 2018 , more than half of the literature on educational administration $(13,341$ publications) was published in the 
U.S. The U.K. ranked second with 2,423 publications. With American domination in educational leadership literature, one might assume that educational leadership would be well-developed in the U.S.

However, the realities are more complex. Levine (2005) points out that since the early $20^{\text {th }}$ century, principal preparation programs in the U.S. have been unsystematic. There remains no consensus on whom to enroll, what to teach, and what degree to offer. Also, no consensus exists on how educational administration relates to classroom teaching and educational research. Studies on principal preparation programs reveal significant deficiencies (Hess, 2013; Hess \& Kelly 2007). In particular, the use of data is not a focus in training future school leaders: students only spend about eleven percent of instruction time to learn about curriculum development, pedagogy, classroom management, and theories of learning. These failings threaten the quality of leadership preparation. Similarly, in her social history of the U.S. principal post, Kate Rousmaniere (2013) portrays the development of the principalship as reflecting bureaucratization and sexism. Rousmaniere sees bureaucratic training requirements for the post as favouring males and describes modern principals as distant authority figures, ineffective in running American schools.

\section{Educational leadership in Vietnam}

Vietnam, on the other hand, is almost invisible on the world's educational leadership literature map. The few studies on educational leadership in Vietnam focus on the recruitment of principals (Nguyen, 2013), Confucian values in school leadership (Truong et al., 2017), instructional leadership style, and elements of institutional hierarchy, relationships with local officials, and the significance of seniority in schools (Hallinger et al., 2017). Nguyen (2013) interviewed ten elementary school leaders from Ho Chi Minh City, Vietnam. They were supervisors, principals, and teachers. The interviews focused on the knowledge and skills of elementary principals as well as the recruitment process. The study suggested insufficiency of knowledge and skill in school management and school leadership among principals. Truong et al. (2017) conducted an intensive qualitative study in three Vietnamese elementary schools. The findings include the significant role of power distance and collectivism in the decision making of Vietnamese school principals. Hallinger et al. (2017) conducted semi-constructed interviews with 27 elementary school principals in Vietnam. Their research reveals a strong emphasis on instructional leadership. Vietnamese principals also focus on building solidarity and managing external relationships, which links to the Confucian norms of collectivism and community harmony.

The significant findings from these studies highlight patriarchy, centralized power, and the importance of hierarchy and seniority in educational leadership in Vietnam. However, all of the studies above face significant limitations. The sample sizes are small, usually about a dozen principals. Most surveyed and interviewed principals are from convenience samples, often from urban places. More importantly, systematic research on principal preparation like Levine's study (2005), Rousmaniere's book, or Hess and Kelly's study (2007) does not exist due to the unavailability of data. Nevertheless, the typical rhetoric about principals in Vietnam differs from that in the U.S. In Vietnam, while principals are figures of authority, they are not viewed as distant nor ineffective. Instead, they are perceived as the "father" figure of a school, someone whom teachers, parents, and students respect. In the Vietnamese culture, Vietnamese people dedicate the third day of the Lunar New Year to appreciate teachers after dedicating the first day of the Lunar New Year to fathers and the second day to mothers. The role of teachers is culturally as important as the role of parents. In part, this may reflect different conceptions of leadership in a traditional society, Vietnam, compared with a rational-legal society, the U.S. (Weber, 1919).

\section{Goals of Education in Two Countries}

In the U.S., the highly influential Cardinal Principles of Secondary Education (1918) propose seven key objectives: Health, command of fundamental processes, worthy home membership, vocation, civic education, worthy use of leisure, and ethical character. The seven principles in the Cardinal Principles of Secondary Education influence how schools prepare career-successful, civically engaged, healthy citizens to serve their families and communities. American educational goals are fundamentally oriented toward vocation rather than the pursuit of general knowledge, or regime continuation.

In Vietnam, the goals are written into education laws. The purposes of secondary education (grades 10-12) are to help students fully develop ethically, emotionally, intellectually, physically, and aesthetically. Schools are also intended to build up the ability, proactiveness, and formation of a socialist Vietnamese citizen; thus, regime continuation is a key-value, given the relatively new Vietnamese state. Schools are to equip students with selflearning skills for higher education and throughout their lives to participate in working, building, and protecting the Fatherland (Vietnam's Education Law). 
The two countries both focus on students' full development, but with fundamental differences. The U.S. emphasizes diversity, democracy, and civic ideals in the framework of a "pluralistic definition of American society" (Mirel, 2020) and "multi-dimensionality of identity" of education (Berry \& Candis, 2013). In contrast, Vietnamese education is a tool to create the vanguards of socialism, where nationalism aided by heroism is the main catalyst (Roszko, 2010; Hoang, 2017). This difference also reflects the history, path to independence, and culture of the two countries. Individualism, localism, and democracy are at the heart of American history. Nationalism, on the other hand, is at the heart of Vietnamese history for the country's four thousand years of building and defending itself against foreign powers.

\section{Path to School Leadership in Two Countries}

In the U.S., principals in traditional public schools are required to have a teaching certificate, have been teaching for at least one year, and have at least a bachelor's degree (Hess, 2013). The majority of principals will need a higher degree in education, educational leadership, or educational management. The degree can be a Master's degree or a Doctorate degree. Principals also need to have certain credentials. Other requirements vary across states. Districts may differ in their specific hiring processes. Overall, the principal hiring process is bureaucratic.

The following description is taken from the principal hiring process at Aurora Public Schools in Colorado (Aurora Public School, n.d.). When there is a vacancy, the job will be publicly posted. Members of the division of instruction and human resources will conduct an in-house application screening and first-round interviews. The superintendent will interview the finalists, and then the superintendent will make a recommendation to the school board. The school board will then conduct a final background check and make an offer to the candidate. The process is supposed to be transparent to the public.

In Vietnam, as in many other national enterprises, public education is heavily centralized, in the strategic plans of each province and district. Personnel policies are also centrally planned. School leaders are selected among "seeds" and through a central democratic process. In this process, party leaders who are the people's representatives will make all decisions. The term "seeds" means those teachers who have earned a good performance rating in teaching competitions and have received good evaluations from the school board (a school board in Vietnam includes the principal, vice principals, and some other department heads). To become a "seed," a teacher must be a member of the Communist Party. When there is a vacancy, the local office of education will nominate candidates to the local Politburo (central committee) for consideration. The Politburo then makes decisions based on quality as well as the ideology of the candidates and how they fit into the broader social, political, and economic strategic plan of the province or district. Elementary and middle school principals are selected at the district level. High school principals are selected at the provincial level. Principals, therefore, enjoy more job security than their counterparts in America. This security could enable principals to focus more on helping students than on keeping their jobs, or conversely, as argued by Anthony Downs (1967), this could attract risk-averse officials to the job. Those who are deemed "seeds" often have large networks within the local party branch. Their firing provokes networks within the party associated with them, which may lead to unexpected consequences for the person who fired the principal. For example, Hallinger et al. (2017) suggest that Vietnamese principals place significant importance on their relationship with senior officials from the local party, which is part of building external relationships to maintain harmony in Confucianism.

Legally, principals cannot serve more than two terms (five years each term) at the same school in Vietnam. However, this law has not been consistently implemented especially in rural and remote places. There are many principals serving more than two terms at the same school (Nguyen, 2010). Reasons include shortage of teachers for many principals also teach (Nguyen, 2019; Ha, 2019), and the fact that many principals do not like rotating to a new environment (Nguyen, 2010).

\section{Comparative Spending, International Performance, and Role of Principals}

Although public education from kindergarten to grade 12 (K-12) is free in Vietnam and the U.S., the two countries differ significantly in their investments in education and their rankings in international assessments. In 2014, the World Bank estimated that the U.S. spent 5\% of its total GDP on public K-12 education. In 2016, the World Bank estimated that Vietnam spent $4.3 \%$ of its total GDP on education. Certainly, the cost of living and the size of the economy in Vietnam is significantly lower and smaller than in the U.S. (Fu \& Hamadeh, 2017). Yet, looking at the percentage of educational expenditure as a percentage of total GDP, the U.S. seems to spend significantly more money on education compared to Vietnam. 
However, American students do not perform as well as Vietnamese students on international assessments. On the PISA test, for example, Vietnamese students rank significantly higher than U.S. students. Vietnamese students are among the top performers while American students are about at the average achievement level. Vietnamese students scored 495 on average while American students scored 470 on average on the mathematics literacy scale. The differences between the two countries are statistically significant (PISA, 2018). Vietnam had a similar share in top performers (12\% for Vietnam and $13.3 \%$ for the U.S.) but had fewer students in the bottom achievers (4.5\%) compared to the U.S. (13.6\%). Vietnam ranks among the top countries while the U.S. is usually slightly above or at the average.

While the focus of the PISA test is students, it is essential to acknowledge that school leadership and structure contribute to student achievement levels. Studies have found that school leaders may have a positive influence on student achievement and teachers' turnover (Leithwood et al., 2004; Learning Policy Institute, 2017). Looking into school leadership may shed light on the differences in achievement across countries. This paper is an attempt to uncover the first layer in school leadership differences between the two countries, focusing on education and training for principals.

\section{MATERIALS AND METHODS}

As noted above, prior works (Nguyen, 2013; Truong, 2013; Hallinger et al., 2017; Hess, 2013; Hess \& Kelly, 2007; Levin, 2015) suggest the following hypotheses:

H1: With more value placed on seniority and experiences in the culture, principals in Vietnam are older and more experienced than principals in the U.S.

H2: Based on the cultural difference that teachers are more respected in Vietnam than in the U.S. within the context of teacher shortages, Vietnamese principals are more likely to teach in the classroom.

H3: Based on the size of the country, its higher income, its diverse student population, and its history of modern education, we hypothesize that education and training for principals in the U.S will be more extensive than in Vietnam.

Data for this study comes from the Organization for Economic Cooperation and Development (OECD) Teaching and Learning International Survey (TALIS) in 2018. The TALIS surveys are "self-reports from teachers and school leaders and, therefore, represent their opinions, perceptions, beliefs, and accounts of their activities," and "no data imputation from administrative data or other studies is conducted" (OECD 2018, p. 20). Many researchers have used the TALIS data to study teacher activities, teacher satisfaction (Sims, 2019) and school culture around the world (Burns \& Darling-Hammond, 2014; Rizza, 2011), as well as student achievement in relationship with teacher quality (Echazarra \& Radinger, 2019). In 2018, the survey covered about 260,000 teachers in 15,000 schools across 48 countries and economies, including Vietnam and the U.S. In this paper, I will only use data at the lower secondary level, grades 7-9 in the U.S. and grades 6-9 in Vietnam. I conducted $t$-test analyses to compare characteristics of principalship and the needs of professional development programs in the U.S. and Vietnam. I recoded categorical variables into binary variables, including questions on principals' needs of professional development programs and principals' opinions on barriers to participating in professional development programs.

The study is the first step to dissect leadership preparations in Vietnam and the U.S. Even though it is descriptive by nature, the study has many potential contributions. First, the study helps to diversify the literature on educational leadership, which the West and English-speaking nation-states have long dominated. Given that cross-country and cultural comparisons are often between countries with comparable histories (for example the United Kingdom and the U.S) or rival positions (China and the U.S. in terms of economic development and cultural differences), the unusual comparison between America and Vietnam on leadership preparation programs may also be helpful for educators in both countries as well as educators from other countries who may share common characteristics with the U.S. and Vietnam. Such common characteristics include economic size, cultural and societal characteristics, and political systems. Certainly, such lessons from this comparative study will need appropriate modifications to fit into the specific country's context. Yet, they are valuable in filling the gaps in our knowledge of educational leadership from an international perspective.

\section{RESULTS AND DISCUSSION}

Table 1 provides summary statistics about selected questions in the study. There were 166 American principals and 196 Vietnamese principals who participated in the survey. Questions include age, gender, experience, working history, and needs for professional development programs in different areas.

Table 2 addresses Hypotheses 1 and 2 in this study, focusing on age, experience, and teaching obligation in schools. I found that American principals are younger than Vietnamese principals $(\mathrm{p}<0.001)$. They also had higher 
education degrees, $t=-35.691$ and $p=0.000$. I did not find a statistical difference regarding years of working experience as a principal at the current school between American principals and Vietnamese principals. However, with regards to total years of working as principals, years of experience at other management positions, and years of teaching, Vietnamese principals seemed to have more experience than their American counterparts. In particular, Vietnamese principals worked 1.6 years more as principals $(t=-2.1, p=0.036), 1.1$ more years working at other management positions $(t=-1.8, p=0.075)$, and 3.7 more years in teaching compared with American principals $(t=-4.3, p=0.000)$. Finally, Vietnamese principals are more likely to teach compared with their American counterparts. Only $2 \%$ of American principals reported having to teach, while $58 \%$ of Vietnamese principals reported having to teach at their schools $(t=-14.245, p=0.000)$.

In this way, as Chubb and Moe (1990) point out, American principals are on a long-term administrative track. The average American public high school principal, for example, has not taught in over a decade. This stands in contrast to private school principals, and charter school principals, who run smaller schools with fewer administrators and, in this way, resemble Vietnamese principals; indeed, some still teach (Maranto, 2015). The findings seem to affirm prior studies (Su et al., 2000): Vietnamese principals are more male, older, and still teaching. That gives them a different role, perhaps that of a more involved father figure rather than a distant authority figure. However, this finding rings an alarm that Vietnam is still behind in diversifying its educational leadership pipeline. Given that researchers suggested that having a woman principal or a greater proportion of women teachers positively correlated with school performance (Campos-García et al., 2019), the need to empower women leaders in school becomes more relevant.

Tables 3, 4, and 5 answer Hypothesis 3, testing the difference in principals' needs and opinion of professional development programs, alluring to the bigger picture of principal training in the two countries. Table 3 suggests that across areas of professional development, Vietnamese principals indicated that they were in higher need of such programs compared to their American counterparts. The smallest gap was the need for professional development programs in designing professional development for/with teachers and designing the school curriculum. The biggest gap was the need for professional development programs in observing classroom instruction, providing effective feedback, developing collaboration among teachers, promoting equity and diversity, and human resources management.

Hess \& Kelly (2007) found that American principal preparation programs suffer significant deficiencies in curriculum development, pedagogy, classroom management, theories of learning, public relations, and data management. However, it is suggestive from the findings that principal preparation programs in Vietnam do not even perform at a comparable level compared to the American programs. These differences may come from the relatively short history of Vietnam's modern unified educational system. Vietnamese leadership, therefore, should focus on providing principals with areas of concern to improve their performance.

Table 1. Summary statistics for characteristics of principalship and professional development programs in the U.S. and Vietnam

\begin{tabular}{|c|c|c|c|c|c|c|c|c|c|c|}
\hline & \multicolumn{5}{|c|}{ U.S. } & \multicolumn{5}{|c|}{ Vietnam } \\
\hline & Obs & Mean & SD & Min & Max & Obs & Mean & SD & Min & Max \\
\hline Female & 166 & 0.367 & 0.484 & 0 & 1 & 196 & 0.275 & 0.448 & 0 & 1 \\
\hline Age (under 50) & 166 & 0.638 & 0.482 & 0 & 1 & 196 & 0.464 & 0.500 & 0 & 1 \\
\hline Bachelor and below & 166 & 0.012 & 0.109 & 0 & 1 & 196 & 0.899 & 0.303 & 0 & 1 \\
\hline $\begin{array}{l}\text { Mean years of working } \\
\text { experience as a principal at } \\
\text { the current school }\end{array}$ & 160 & 4.762 & 4.769 & 0 & 30 & 196 & 4.883 & 3.985 & 0 & 28 \\
\hline $\begin{array}{l}\text { Mean total years working } \\
\text { as principals }\end{array}$ & 160 & 7.537 & 6.675 & 0 & 36 & 196 & 9.133 & 7.481 & 0 & 40 \\
\hline $\begin{array}{l}\text { Years of experience at } \\
\text { other management } \\
\text { positions before becoming } \\
\text { principals }\end{array}$ & 159 & 5.503 & 4.89 & 0 & 27 & 196 & 6.612 & 6.471 & 0 & 34 \\
\hline Years of teaching & 160 & 11.231 & 6.867 & 0 & 44 & 196 & 14.888 & 8.786 & 1 & 38 \\
\hline $\begin{array}{l}\text { Teaching obligation with } \\
\text { principalship }\end{array}$ & 166 & 0.018 & 0.134 & 0 & 1 & 196 & 0.582 & 0.494 & 0 & 1 \\
\hline
\end{tabular}


Professional development needs: 1 = No need at present; $2=$ Low level of need; 3 = Moderate level of need; $4=$ High level of need

\begin{tabular}{|c|c|c|c|c|c|c|c|c|c|c|}
\hline $\begin{array}{l}\text { Knowledge and } \\
\text { understanding of new } \\
\text { developments in leadership } \\
\text { research and theory }\end{array}$ & 160 & 2.262 & 0.740 & 1 & 4 & 196 & 3.525 & 0.611 & 1 & 4 \\
\hline $\begin{array}{l}\text { Knowledge and } \\
\text { understanding of current } \\
\text { national /local policies on } \\
\text { education }\end{array}$ & 160 & 2.419 & 0.722 & 1 & 4 & 194 & 3.613 & 0.519 & 1 & 4 \\
\hline $\begin{array}{l}\text { Using data for improving } \\
\text { the quality of the school }\end{array}$ & 160 & 2.575 & 0.789 & 1 & 4 & 196 & 3.663 & 0.515 & 2 & 4 \\
\hline $\begin{array}{l}\text { Designing the school } \\
\text { curriculum }\end{array}$ & 160 & 2.241 & 0.799 & 1 & 4 & 196 & 3.500 & 0.775 & 1 & 4 \\
\hline $\begin{array}{l}\text { Designing professional } \\
\text { development for/with } \\
\text { teachers }\end{array}$ & 160 & 2.556 & 0.837 & 1 & 4 & 196 & 3.423 & 0.686 & 1 & 4 \\
\hline $\begin{array}{l}\text { Observing classroom } \\
\text { instruction }\end{array}$ & 160 & 2.044 & 0.712 & 1 & 4 & 196 & 3.541 & 0.643 & 1 & 4 \\
\hline $\begin{array}{l}\text { Providing effective } \\
\text { feedback }\end{array}$ & 160 & 2.219 & 0.774 & 1 & 4 & 196 & 3.561 & 0.556 & 2 & 4 \\
\hline $\begin{array}{l}\text { Promoting equity and } \\
\text { diversity }\end{array}$ & 160 & 2.194 & 0.765 & 1 & 4 & 196 & 3.534 & 0.602 & 2 & 4 \\
\hline $\begin{array}{l}\text { Developing collaboration } \\
\text { among teachers }\end{array}$ & 160 & 2.269 & 0.767 & 1 & 4 & 196 & 3.755 & 0.465 & 2 & 4 \\
\hline $\begin{array}{l}\text { Human resource } \\
\text { management }\end{array}$ & 160 & 2.169 & 0.848 & 1 & 4 & 196 & 3.684 & 0.565 & 1 & 4 \\
\hline Financial management & 160 & 2.362 & 0.894 & 1 & 4 & 196 & 3.658 & 0.633 & 1 & 4 \\
\hline
\end{tabular}

Professional development activities participated in the past 12 months aimed at principals: $0=$ No; $1=$ Yes $\begin{array}{lllllllllll}\text { Subject matter, teaching } & 166 & 0.765 & 0.425 & 0 & 1 & 196 & 0.852 & 0.356 & 0 & 1\end{array}$ methods or pedagogical topics

\begin{tabular}{lcccccccccc}
\hline Leadership & 166 & 0.837 & 0.370 & 0 & 1 & 196 & 0.755 & 0.431 & 0 & 1 \\
\hline Education conferences & 166 & 0.710 & 0.443 & 0 & 1 & 196 & 0.730 & 0.445 & 0 & 1 \\
\hline $\begin{array}{l}\text { Participation in a network } \\
\text { of principals }\end{array}$ & 166 & 0.735 & 0.443 & 0 & 1 & 196 & 0.556 & 0.498 & 0 & 1 \\
\hline $\begin{array}{l}\text { Reading professional } \\
\text { literature }\end{array}$ & 166 & 0.928 & 0.260 & 0 & 1 & 196 & 0.985 & 0.123 & 0 & 1 \\
\hline
\end{tabular}

\begin{tabular}{|c|c|c|c|c|c|c|c|c|c|c|}
\hline \multicolumn{11}{|c|}{$\begin{array}{l}\text { Barriers to participation in professional development programs: } 0=\text { Strongly disagree/Disagree; } \\
1=\text { Agree/Strongly agree }\end{array}$} \\
\hline $\begin{array}{l}\text { I do not have the pre- } \\
\text { requisites }\end{array}$ & 166 & 0.036 & 0.182 & 0 & 1 & 196 & 0.133 & 0.340 & 0 & 1 \\
\hline $\begin{array}{l}\text { Professional development } \\
\text { is too expensive }\end{array}$ & 166 & 0.259 & 0.439 & 0 & 1 & 196 & 0.153 & 0.361 & 0 & 1 \\
\hline $\begin{array}{l}\text { There is a lack of } \\
\text { employer support }\end{array}$ & 166 & 0.108 & 0.312 & 0 & 1 & 196 & 0.978 & 0.486 & 0 & 1 \\
\hline $\begin{array}{l}\text { Professional development } \\
\text { conflicts with my work } \\
\text { schedule }\end{array}$ & 166 & 0.506 & 0.501 & 0 & 1 & 196 & 0.352 & 0.479 & 0 & 1 \\
\hline
\end{tabular}




\begin{tabular}{lllllllllll}
\hline & \\
\hline $\begin{array}{l}\text { I do not have time because } \\
\text { of family responsibilities }\end{array}$ & 166 & 0.295 & 0.457 & 0 & 1 & 196 & 0.036 & 0.186 & 0 & 1 \\
\hline $\begin{array}{l}\text { There are no incentives for } \\
\text { participating in } \\
\text { professional development }\end{array}$ & 166 & 0.289 & 0.455 & 0 & 1 & 196 & 0.291 & 0.455 & 0 & 1 \\
\hline
\end{tabular}

Table 2. Comparing characteristics of principalship between US and Vietnam (Mean US - Mean Vietnam)

\begin{tabular}{|c|c|c|c|}
\hline Variable & Mean difference & $t$-value & Prob \\
\hline Age (under 50) & 0.174 & 3.359 & 0.001 \\
\hline Bachelor and below & -0.886 & -35.691 & 0.000 \\
\hline $\begin{array}{l}\text { Mean years of working experience as a principal at the current } \\
\text { school }\end{array}$ & -0.120 & 0.259 & 0.796 \\
\hline Mean total years working as principals & -1.595 & -2.100 & 0.036 \\
\hline $\begin{array}{l}\text { Years of experience at other management positions before } \\
\text { becoming principals }\end{array}$ & -1.109 & -1.786 & 0.075 \\
\hline Years of teaching & -3.656 & -4.300 & 0.000 \\
\hline Teaching obligation with principalship & -0.563 & -14.245 & 0.000 \\
\hline
\end{tabular}

Table 3. Comparing needs of professional development of principals between US and Vietnam (Mean $U S-$ Mean $_{\text {Vietnam }}$ )

\begin{tabular}{|c|c|c|c|}
\hline $\begin{array}{c}\text { Variable: moderate or higher need of professional } \\
\text { development programs }\end{array}$ & Mean difference & $t$-value & Prob \\
\hline $\begin{array}{l}\text { Knowledge and understanding of new developments in } \\
\text { leadership research and theory }\end{array}$ & -0.539 & -13.770 & 0.000 \\
\hline $\begin{array}{l}\text { Knowledge and understanding of current national /local policies } \\
\text { on education }\end{array}$ & -0.519 & -14.337 & 0.000 \\
\hline Using data for improving the quality of the school & -0.437 & -11.713 & 0.000 \\
\hline Designing the school curriculum & -0.434 & -10.145 & 0.000 \\
\hline Designing professional development for/with teachers & -0.406 & -9.752 & 0.000 \\
\hline Observing classroom instruction & -0.710 & -20.048 & 0.000 \\
\hline Providing effective feedback & -0.590 & -15.834 & 0.000 \\
\hline Promoting equity and diversity & -0.600 & -15.622 & 0.000 \\
\hline Developing collaboration among teachers & -0.575 & -15.756 & 0.000 \\
\hline Human resource management & -0.592 & -15.649 & 0.000 \\
\hline Financial management & -0.514 & -13.152 & 0.000 \\
\hline
\end{tabular}

Table 4. Comparing professional development participation between US and Vietnam (Mean US - Mean Vietnam) in the past 12 months

\begin{tabular}{lccc}
\hline \multicolumn{1}{c}{ Variable: attended professional development programs } & Mean difference & $\boldsymbol{t}$-value & Prob \\
\hline Subject matter, teaching methods or pedagogical topics & -0.087 & -2.118 & 0.035 \\
\hline Leadership & 0.082 & 1.928 & 0.055 \\
\hline Education conferences & -0.019 & 0.395 & 0.693 \\
\hline Participation in a network of principals & 0.179 & 3.580 & 0.000 \\
\hline Reading professional literature & -0.057 & -2.731 & 0.007 \\
\hline
\end{tabular}

Table 5. Comparing barriers to participating in professional development of principals between US and Vietnam (Mean US - Mean Vietnam)

\begin{tabular}{lccc}
\hline \multicolumn{1}{c}{ Variable: agree/strongly agree } & Mean difference & $\boldsymbol{t}$-value & Prob \\
\hline I do not have the pre-requisites & -0.096 & -3.261 & 0.001 \\
\hline Professional development is too expensive & 0.106 & 2.519 & 0.012 \\
\hline
\end{tabular}




\begin{tabular}{lccc}
\hline There is a lack of employer support & -0.269 & -6.142 & 0.000 \\
\hline Professional development conflicts with my work schedule & 0.154 & 2.983 & 0.003 \\
\hline I do not have time because of family responsibilities & 0.259 & 7.264 & 0.000 \\
\hline There are no incentives for participating in professional development & -0.002 & 0.035 & 0.972 \\
\hline
\end{tabular}

Table 4 reports differences between participation in professional development programs in the past 12 months. I found that American principals attended fewer programs regarding subject matter, teaching methods or pedagogical topics $(t=-2.118, p=0.035)$ and reading professional literature $(t=-2.731, p=0.007)$ compared with Vietnamese principals. Vietnamese principals, however, attended fewer programs focusing on leadership $(t=1.928, p=0.055)$ and networking $(t=3.580, p=0.000)$.

In other words, American principals had less need for courses/seminars about the subject matter, teaching methods, or pedagogical topics as part of formal education and training compared to their Vietnamese counterparts. They needed more training programs in networking formed specifically for the professional development of principals compared to their Vietnamese counterparts, as networking is embedded in the Anglo-American culture. These findings resonate with the difference in cultural emphasis between the two cultures (Lo, 2012). In Eastern culture, networking emphasizes reciprocity, a long-term time orientation, and culture-specific etiquette. In AngloAmerican Western culture, networking is critical to individuals' business successes and does not necessarily share similarities with Eastern cultural norms. Networking for Vietnamese principals may mean deep reciprocal and longterm relationships within a limited circle (Hallinger et al., 2017) while American principals may mean more practical relationships to their success, therefore, with no limiters.

Table 5 compares barriers to participating in professional development among American and Vietnamese principals. I found that monetary cost of participation $(t=2.519, p=0.012)$, scheduling conflicts $(t=2.983, p=0.003)$, and family responsibilities $(t=7.264, p=0.000)$ were more prevalent to American principals compared with their Vietnamese counterparts. On the other hand, Vietnamese principals were more likely to lack pre-requisites $(t=-3.261$, $p=0.001)$ and employer support $(t=-6.142, p=0.000)$ to participate in professional development programs.

There are two likely explanations for the differences in principal opinions across the two countries. First, the principal training and teacher training in Vietnam, indeed, insufficiently prepare principals; therefore, they are at a high level of need for professional development programs. Second, Vietnamese principals could be modest about their training. This modesty reflects a culture of humility, especially in interactions with outsiders (in this case, the survey was conducted by OECD). Comparative studies on student non-cognitive outcomes have indicated that there are differences in responses across countries because of differences in cultural norms. For example, different groups of students have different interpretations when being asked to evaluate a teacher's classroom management skills or his or her efforts (Vonkova et al., 2018). Studies on self-esteem and culture also suggest differences between cultures in selfevaluating manners (Cai et al., 2007; Becker et al., 2014). Therefore, we can expect the same phenomenon among principals in different countries. Especially given the cultural findings that East Asian people are less inclined to evaluate themselves in an excessively positive manner (Cai et al., 2007), we can suspect a similar conclusion regarding Vietnamese principals: They are also less inclined to positively evaluate themselves compared to American principals.

In short, findings tend to confirm all hypotheses. First, Vietnamese principals are older and more experienced than their American counterparts. Second, findings also suggest that Vietnamese principals are more likely to teach in the classroom; however, they also tend to lack formal education and training for which they look for in professional development programs as supplements.

\section{CONCLUSION}

The paper offers many potential contributions. First, it will be the first of its kind to compare educational leadership preparation in the U.S. and in Vietnam. Second, it is among the few systematic studies including a moderately large number of Vietnamese principals, allowing quantitative analyses. Third, given the push for education reform, a comparative study may offer insights for both countries. Lastly, this study contributes to diversifying the literature on educational leadership which the West has long dominated.

The findings from comparing lower secondary school principals have revealed significant differences between those in the U.S. and those in Vietnam. From the TALIS 2018 national dataset, it appears that the training programs for principals in the U.S. are more comprehensive and thorough compared to Vietnam. Principals in the U.S. are also younger, and they have less experience working in other management positions before becoming principals. They also do not teach after accepting the position; indeed, typically they have not taught for several years before taking 
the position, instead of doing administrative work. Thus, American principals might have somewhat less knowledge about teachers and teaching, making it more difficult for them to practice instructional leadership with credibility (Chubb \& Moe, 1990; Maranto, 2015). However, given the inherent differences between the two countries, such findings should be used with caution when including them in the discussion about student achievement.

As mentioned earlier, this study is the first attempt to unearth the similarities and differences between education and training programs for principals in the U.S. and Vietnam. In future studies, I will follow up with future surveys from TALIS to study the trends in leadership over the years. In addition, I plan to expand the comparison, such as grouping countries with similar politics and cultures or those from the same continent, in order to detect common cultural patterns in school leadership. Lastly, I will improve the study by including school location and enrolment to examine possible differential patterns in school leadership based on schools' characteristics.

\section{Limitations and Future Research}

The study, however, faces limitations. Even though the study has the greatest number of principals for Vietnam $(n=196)$, it is still a small sample ( $n=166$ for the U.S.). This sample, therefore, is not representative of the two countries. Second, no causal inference can be drawn regarding the difference in student achievement as a function of principals' educational backgrounds between the U.S. and Vietnam. In addition, elements of political, social, and cultural differences that may affect perceptions and definitions of professional development programs are also important.

Nevertheless, conversations on school leadership in general, and comparative school leadership in particular, may still shed light on how to improve the quality of education within and across countries not only for the U.S. and Vietnam, but also for countries that may share similarities in culture, society, economy, and political structure with Vietnam and the U.S. More importantly, this study helps fill in gaps in knowledge about educational leadership around the world, which the West has dominated for a long time. The area of comparative educational leadership, in general, still provides valuable information for academic researchers, policymakers, and educational practitioners, especially in the contemporary era of increasing interconnectedness and globalisation.

Conflict of Interest: No potential conflict of interest relevant to this article was reported.

Funding: The authors received no financial support for this article.

\section{REFERENCES}

Anckar, C. (2008). On the applicability of the most similar systems design and the most different systems design in comparative research. International Journal of Social Research Methodology: Theory \& Practice, 11(5), 389401. https://doi.org/10.1080/13645570701401552

Arar, K., Beycioglu, K., \& Oplatka, I. (2017). A cross-cultural analysis of educational leadership for social justice in Israel and Turkey: Meanings, actions, and contexts. Compare: A Journal of Comparative and International Education, 47(2), 192-206. https://doi.org/10.1080/03057925.2016.1168283

Aravena, F. (2016). Preparing school principals in the Chilean scenario: Lessons from Australia, England and the united states. Journal of Educational Administration and History, 48(4), 342. https://doi.org/10.1080/ 00220620.2016 .1210586

Aurora Public School (n.d.). Aurora Public Schools' Principal Hiring Process. Division of Human Resources. Retrieved from https://aurorak12.org/hr/adminhiresteps.pdf

Becker, M., Vignoles, V. L., Owe, E., Easterbrook, M. J., Brown, R., Smith, P. B. Koller, S. H. (2014). Cultural Bases for Self-Evaluation: Seeing Oneself Positively in Different Cultural Contexts. Personality and Social Psychology Bulletin, 40(5), 657-675. https://doi.org/10.1177/0146167214522836

Brundrett, M. (2001). The development of school leadership preparation programmes in England and the USA: A comparative analysis. Educational Management \& Administration, 29(2), 229-245.

Bureau of Economic Analysis (2020). News Release. U.S. Department of Commerce. Retrieved from https://www.bea.gov/news/2020/gross-domestic-product-fourth-quarter-and-year-2019-advance-estimate

Burns, D. \& Darling-Hammond, L., (2014). Teaching Around the World: What Can TALIS Tell Us?. Stanford, CA: Stanford Center for Opportunity Policy in Education.

Cai, H., Brown, J. D., Deng, C., \& Oakes, M. A. (2007). Self-esteem and culture: Differences in cognitive selfevaluations or affective self-regard?. Asian Journal of Social Psychology, 10(3), 162-170. https://doi.org/10.1111/ j.1467-839X.2007.00222.x 
Campos-García, I., \& Zúñiga-Vicente, J. Á. (2019). The female presence in different organisational positions and performance in secondary schools: Does a woman leader function as mediator?. PloS one, 14(9), e0222411. https://doi.org/10.1371/journal.pone.0222411

Chao, C., \& Tian, D. (2011). Culturally Universal or Culturally Specific: A Comparative Study of Anticipated Female Leadership Styles in Taiwan and the United States. Journal of Leadership \& Organizational Studies, 18, 64-79.

Chen, Y., Cheng, J., \& Sato, M. (2017). Effects of school principals' leadership behaviours: A comparison between Taiwan and Japan. Educational Sciences: Theory \& Practice, 17(1), 145-173. https://doi.org/10.12738/estp.2017.1.0018

Chubb, J. E. \& Moe, T. M. (1990). Politics, Markets, and America's Schools. Washington: Brookings Institution Press.

Downs, A. (1967). Inside bureaucracy (Reissu 1994. ed.). Prospect Heights, IL: Waveland Press.

Echazarra, A., Radinger, T. (2019). Learning in rural schools: Insights from PISA, TALIS and the literature. OECD Education Working Papers, 196. OECD Publishing. https://doi.org/10.1787/8b1a5cb9-en

$\mathrm{Fu}, \mathrm{H} . \mathrm{S}$, Hamadeh N. (2020). New results from the International Comparison Program shed light on the size of the global economy. Retrieved from https://blogs.worldbank.org/opendata/new-results-international-comparisonprogram-shed-light-size-global-economy

Ha, L. (2019). New academic year begins, but teacher and classroom shortages still exist. Vietnamnet Global. Retrieved from https://vietnamnet.vn/en/society/new-academic-year-begins-but-teacher-and-classroom-shortagesstill-exist-566103.html

Hallinger, P., Walker, A., Nguyen, D. T. H., Truong, T., \& Nguyen, T. T. (2017). Perspectives on principal instructional leadership in Vietnam: a preliminary model. Journal of Educational Administration, 55(2), 222239. https://doi.org/10.1108/JEA-11-2015-0106

Hess, F. M. (2013). Cage-busting leadership. Cambridge, Mass: Harvard Education Press.

Hess, F., \& Kelly, A. (2007). Learning to lead: What gets taught in principal-preparation programs. Teachers College Record, 109(1), 244-274.

Hoang, H. T. H. (2017). How the Vietnamese cult of heroes promotes nationalism in politics. The Conversation. Retrieved from https://theconversation.com/how-the-vietnamese-cult-of-heroes-promotes-nationalism-inpolitics-73144

Learning Policy Institute (2017). The role of principals in addressing title teacher shortages. Palo Alto, CA: Learning Policy Institute.

Leithwood, K., Louis, K. S., Anderson, S., \& Wahlstrom, K. (2004). Review of research How leadership influences student learning.

Levine, A., \& Education Schools Project (2005). Educating school leaders. Education Schools Project.

Lo, K. D. (2012). Chinese Guanxi and Anglo-American Networking: A Comparative Investigation of Cross-Cultural Interpersonal Business Relationships. Journal of International Management Studies, 7(2), 1993-1034.

Maranto, R. (2015). Did the Teachers Destroy the School? Public Entrepreneurship as Creation and Adaptation. Journal of School Leadership, 25(1), 69-101.

Mirel, J. (2002). Civic education and changing definitions of American identity, 1900-1950. Educational Review, 54(2), 143-152. https://doi.org/10.1080/00131910220133239

Nguyen, D. (2010). Rotating school principals. Ho Chi Minh City Online Newspaper for Education. Retrieved from https://www.giaoduc.edu.vn/luan-chuyen-hieu-truong.htm

Nguyen, L. (2019). Vietnam battles preschool teacher shortage crisis. Saigon Giai Phong Online. Retrieved from https://sggpnews.org.vn/education/vietnam-battles-preschool-teacher-shortage-crisis-83096.html

Nguyen, T. H. (2013). Recruitment of School Principals in Vietnam: Using Evidence for Changing Appointment Policies. Asian Journal of Humanities and Social Sciences (AJHSS), 1(3), 132-140.

OECD (2018). PISA 2015 Results in Focus. PISA, OECD Publishing, Paris. Retrieved from https://www.oecd.org/ pisa/pisa-2015-results-in-focus.pdf

OECD (2018). TALIS 2018 Questionnaire. Retrieved from https://www.oecd.org/education/school/TALIS-2018MS-Principal-Questionnaire-ENG.pdf

OECD (2018). TALIS 2018 Technical Report. Retrieved from https://www.oecd.org/education/talis/TALIS_2018_ Technical_Report.pdf

Real time world statistics. (n.d.). Retrieved May 25, 2020, from https://www.worldometers.info 
Regina Berry, T., \& Reese Candis, M. (2013). Cultural Identity and Education: a critical race perspective. Educational Foundations, (Summer-Fall), 43-64.

Retna, K. S. (2015). Different approaches to the professional development of principals: A comparative study of New Zealand and Singapore. School Leadership \& Management, 35(5), 524. https://doi.org/10.1080/ 13632434.2015.1107038

Riley, K. A., \& Louis, K. S. (Eds.). (2000). Leadership for change and school reform: International perspectives. Psychology Press.

Rizza, C. (2011). New Teachers' Working Experience: A Secondary Analysis of TALIS. In Back to the Future: Legacies, Continuities and Changes in Educational Policy, Practice and Research. Centro de Investigação em Educação (CIEd), Instituto de Educação, Universidade do Minho.

Roszko, E. (2010). Commemoration and the state: Memory and legitimacy in Vietnam. Sojourn, 25(1), 1-28. https://doi.org/10.1355/SJ25-1A

Rousmaniere, K. (2013). The Principal's Office: A Social History of the American School Principal. Albany: State University of New York Press.

Storey, V. A. (2018). A comparative analysis of the education policy shift to school type diversification and corporatization in England and the United States of America: Implications for educational leader preparation programs. International Journal of Educational Leadership Preparation, 13(1), 1.

Su, Z., Adams, J., \& Mininberg, E. (2000). Profiles and preparation of urban school principals - A comparative study in the United States and China. Education and Urban Society, 32(4), 455-480.

Tang, H. V., Yin, M., \& Min, J. C. H. (2011). A comparative study of educational leadership in Taiwan and the USA. African Journal of Business Management, 5(1), 30-38.

Truong, T. D., Hallinger, P., \& Sanga, K. (2017). Confucian values and school leadership in Vietnam: Exploring the influence of culture on principal decision making. Educational Management Administration \& Leadership, 45(1), 77-100. https://doi.org/10.1177/1741143215607877

UNESCO (2020). Education: percentage of female teachers by teaching level of education. UNESCO Data. Retrieved from http://data.uis.unesco.org/index.aspx?queryid=178

Vietnam's National Assembly (2019). Vietnam's Education Law Act of 43/2019.

Vogel, L. R. (2015). Values and context: Taiwan principal preparation and practice from an American perspective. International Journal of Educational Administration and Policy Studies, 7(2), 47.

Vonkova, H., Zamarro, G. and Hitt, C. (2018), Cross-Country Heterogeneity in Students' Reporting Behaviour: The Use of the Anchoring Vignette Method. Journal of Educational Measurement, 55, 3-31. https://doi.org/10.1111/ jedm. 12161

Walker, A., \& Dimmock, C. (2002). Cross-cultural comparative insights into educational administration and leadership. School leadership and administration: adopting a cultural perspective (London, RoutledgeFalmer), 13-32.

Weber, Max (2015). "Politics as Vocation" in Weber's Rationalism and Modern Society. Edited and Translated by Tony Waters and Dagmar Waters, New York: Palgrave Macmillan, 2015, pp. 129-198.

Weinstein, J., Azar, A., \& Flessa, J. (2018). An ineffective preparation? The scarce effect in primary school principals' practices of school leadership preparation and training in seven countries in Latin America. Educational Management Administration \& Leadership, 46(2), 226-257. https://doi.org/10.1177/1741143217728083

World Bank (2019). Government expenditure on education, total (\% of GDP). World Bank Data. Retrieved from https://data.worldbank.org/indicator/SE.XPD.TOTL.GD.ZS

World Bank (2020). "Vietnam" in World Bank Data. Retrieved from https://data.worldbank.org/country/vietnam 